\title{
Ringing the Bell on the NYSE: Might a Nonprofit Stock Exchange Have Been Efficient?
}

Stephen F. Diamond

Santa Clara University School of Law, sdiamond@scu.edu

Follow this and additional works at: http://digitalcommons.law.scu.edu/facpubs

Part of the Law Commons

\section{Automated Citation}

Stephen F. Diamond, Ringing the Bell on the NYSE: Might a Nonprofit Stock Exchange Have Been Efficient? (2007), Available at: http://digitalcommons.law.scu.edu/facpubs/466

This Article is brought to you for free and open access by the Faculty Scholarship at Santa Clara Law Digital Commons. It has been accepted for inclusion in Faculty Publications by an authorized administrator of Santa Clara Law Digital Commons. For more information, please contact sculawlibrarian@gmail.com. 


\title{
Ringing the Bell on the NYSE: Might a Nonprofit Stock Exchange Have Been Efficient?
}

\author{
Stephen F. Diamond \\ Jennifer W. Kuan
}

\section{INTRODUCTION}

On March 7, 2006, the New York Stock Exchange announced the completion of its merger with publicly traded Archipelago Holdings, Inc., thus finishing its transformation from a nonprofit membership organization to a standard for-profit corporation.' The decision to change organizational form - to "demutualize" caps a decade-long trend among stock exchanges around the world. ${ }^{2}$ The arguments in favor of demutualization offered in the scholarly and popular literature are varied. They typically contend that a for-profit firm is better able to make new investments, especially in technology, and that for-profits are more responsive to heightened competition from other exchanges. It is also argued that, by placing the assets of an exchange in a corporation whose shares itself are traded, the competitive pressures of the capital markets will drive the new entity to more efficient behavior than that of the "clubby," insular - and outdated - nonprofit.

But few have considered the possibility that the NYSE in its nonprofit form was an efficient organization. Despite dramatic changes in its surrounding environment, the NYSE maintained that form for more than 200 years, undergoing only moderate structural change in response to periodic crises. Right up to its debut as a publicly traded for-profit, the NYSE remained the single largest and most prestigious exchange in the world. ${ }^{3}$ We wish to consider whether or not that stability of form was a rational response to a so-called "lemons" problem. Economist George Akerlof stated the lemons problem in its classic form when he argued

1. See NYSE Group, News Release, New York Stock Exchange/Archipelago Holdings Merger Complete, Mar. 7, 2006, available at http://www.nyse.com/press/ 1141729824519.html.

2. Rubin LeE, What is aN Exchange? The aUtomation, Management, aND REGULATION OF FINANCLAL MARKETS (1998).

3. Jennifer Hughes \& John Authers, Taking the Floor: How a Screen Role Will Challenge New York's Market Debutant, Fin. TIMES, Mar. 7, 2006, at 13. 
that asymmetric information between buyers and sellers in the market for used cars would allow bad cars to drive out good cars over time." At the NYSE, the potential for a lemons problem exists because of the difficulty in extracting truthful information about firms whose shares trade on the NYSE (Issuing Firms) and then persuading investors of that truthfulness.

To analyze the nonprofit NYSE as the solution to an information problem, we apply a theory that views a nonprofit as a consumer-owned entity. In particular, we describe a general model of nonprofits in which the highest demanding consumers of a nonrival good organize themselves to produce that good together. In the case of the NYSE the non-rival good is "liquidity," which we define as the ability to act in the market as a price-taker and which provides enormous benefits to Issuing Firms and investors. The high demanders are financial intermediaries; thus, we focus our attention on investment banks for the purposes of understanding the lemons problem. As intermediaries between large investors and firms seeking to issue securities, banks have special access to information from issuing firms.

How does a nonprofit NYSE, organized by investment bankers to produce liquidity, overcome its lemons problem? We describe two mechanisms that bankers might employ. First, during the listing process, bankers research prospective issuers and screen out bad firms. A second mechanism, which has been observed in venture capital (VC) deals, ${ }^{5}$ is the exchange of "hostages" to motivate truthful disclosure of information by insiders at issuing firms. Insiders always know more about their firms than outside bankers, no matter how sophisticated the diligence process. Information quality is always a potential problem, since insiders may wish to misrepresent the financial condition of their firms. ${ }^{6}$ As underwriters, bankers allocate shares of an IPO to the insiders of other listed firms. These IPO allocations typically come with an expectation that the shares be held for some period of time (a "lock-up"

4. George Akerlof, The Market for "Lemons": Quality Uncertainty and the Market Mechanism, 84 Q. J. ECON. 488, 489-490 (1970).

5. Jennifer Kuan, The Role of Hostages in Establishing Venture Capital Networks, 2005, available at http://siepr.stanford.edu/programs/SST Seminars/ Role of Hostages in VC.pdf (last visited Feb. 18, 2007).

6. The literature on the problem of inside managers taking advantage of outside investors is vast and reaches back to Smith and Marx, but the classic statement is ADOLF A. Berle \& Gardiner MEANS, THE MOdern CORPORATION aNd PRIVATE ProperTy (1932). For a recent review of the problem, see William W. Bratton, Berle and Means Reconsidered at the Century's Tum, 26 J. CORP. L. 737 (2001). 
period), Internet-bubble behavior notwithstanding. This lock-up served a dual purpose, stabilizing the stock price of a new issue and creating mutual vulnerabilities to bad information among insiders of issuing firms. That is, if the CEO of an issuing firm were to lie about his firm to the investing public, insiders at other listed firms who own shares in his firm, i.e. peers, would suffer as well. While this may not seem a large deterrent, and does not perhaps rise to the level of hostage taking in VC financing, we believe there are indications that scrutiny by one's peers matters.

During the 200-year history of the NYSE's operation as a nonprofit, first as a membership association and later as a formal nonprofit corporation, the Exchange's members ${ }^{7}$ carefully decided which firms could trade on the Exchange and then extracted hostages in order to motivate firms to disclose information truthfully. With the demutualization of the NYSE now complete, the era of the banker-owner is at an end. What does a for-profit NYSE portend? We argue that as bankers relinquish ownership of the Exchange they also give up control of the Exchange and will thus also give up their formal role as gatekeepers. The for-profit Exchange will assume the role of gatekeeper. But if the business model of existing for-profit exchanges like Archipelago are any guide, a for-profit exchange, which profits directly from trading volume, is unlikely to be as selective as bankers, who profited only indirectly from trading profits. ${ }^{8}$ But selection is only part of the

7. For the purposes of this paper we will not discuss whether there is a significant difference between the period of investment banking dominance of the Exchange and the pre-banker dominant period of the Exchange. As one history of the earliest activity of the Exchange demonstrates, the Exchange (then called the New York Stock and Exchange Board) itself served as gatekeeper for new listings during that earlier period. See Stuart Banner, The Origin of The New York Stock Exchange, 1791-1860, 27 J. LEGAL STUDIES 113, 127-28 (1998). As far back as 1869 the Exchange had created listing standards assuring investors that they had accurate information regarding the capital structure of firms. See Paul G. Mahoney, The Allocation of Government Authority: The Exchange as Regulator, 83 VA. L. REv. 1453, 1461-1462 (1997). We assume here for the sake of argument that a form of hostage taking has prevailed during at least the investment banking dominant period. There is some evidence that it was in fact the rise to prominence of the investment banks' role in listing securities, complete by 1900 , rather than later federalization of disclosure requirements, that was key to the establishment of a credible modern disclosure regime. See $\mathbf{J}$. Bradford De Long, Did J.P. Morgan's Men Add Value? An Economist's Perspective onFinancialCapitalism, 1990, available at http://www.j-bradford-delong.net/pdf files/Morgan Temin.pdf (last visited Feb. 18, 2007); Mahoney, supra, at 1469-70. In fact, more detailed historical work may demonstrate that the modern hostage system emerged only after trial and error. Anecdotal evidence suggests that the Exchange had to weather quite volatile periods in its early years as non-repeat players behaved opportunistically. For detailed discussion of the hostage mechanism in the modern era, see discussion in Part IV.D. infra.

8. Roberta S. Karmel, Turning Seats Into Shares: Causes and Implications of Demutualization of Stock and Futures Exchanges, 53 HASTINGS L. J. 367 (2002). 
NYSE's success. Unless a for-profit exchange can also facilitate hostage exchange through IPO allocations, firms' incentive to disclose will never be as great as under nonprofit ownership of the NYSE. Without hostages motivating issuers to disclose, ${ }^{9}$ the quality and reliability of information they provide will deteriorate and a lemons problem could potentially reemerge.

\section{Literature on ExChange Demutualization}

Much of the literature on stock exchange demutualization focuses on various perceived weaknesses of the non-profit mutual organization. ${ }^{10}$ According to this literature, decision-making at a nonprofit exchange is problematic because nonprofit decisions require consensus, ${ }^{11}$ respond to a median voter that shifts as membership diversifies, ${ }^{12}$ or produce an increasingly insular, "clubby" membership. ${ }^{13}$ Demutualization should bring about better, faster decisions as the for-profit responds to the market for corporate control,$^{14}$ by investing in new technology, for example. ${ }^{15}$ The timing of demutualization is largely seen as being brought about by new competition from electronic communications networks, or ECN's, ${ }^{16}$ but also by an increase in trading volume internationally, the integration of capital markets globally, and decimalization. ${ }^{17}$

9. It should go without saying that there is little evidence that the agency and other problems that cause opportunistic behavior by firms' senior insiders have diminished as the Exchange has moved towards demutualization. Consider, for example, the recent outbreak of manipulation of stock options, particularly in the high tech sector. See Mark Boslet \& Mark Maremont, Options Backdating Scheme Gets Aired Out, WALL ST. J., Feb. 19, 2007, available at http://online.wsj.com/article/SB117176028286012442.html? mod=2 12271 .

10. Lee provides a descriptive catalogue of recent stock market demutualizations around the world. See LEE, supra note 2. On the world of emerging alternative trading systems, see generally Karmel, supra note 8.

11. See Reena Aggarwal, Demutualization and Corporate Governance of Stock Exchanges, 15 J. APPLIED CORP. FIN. 105, 113 (2002).

12. Oliver Hart \& John Moore, The governance of exchanges: members' cooperatives versus outside ownership, 12 OXfORD REV. ECON. POLICY. 53 (1996); Jonathan R. Macey \& Maureen O'Hara, From Markets to Venues: Securities Regulation in an Evolving World, 58 STAN. L. REV. 563 (2005).

13. Caroline Bradley, Demutualization of Financial Exchanges: Business as Usual? 21 NW. J. INT'L L. \& BuS. 657 (2001).

14. Id. at 668-669.

15. Aggarwal supra note 11.

16. ECN's are electronic trading platforms that allow buyers and sellers to match orders directly without routing the order to a broker-dealer (Nasdaq) or specialist (NYSE). The Nasdaq is an "alternative trading system" because it is simply a network of brokerdealers without a trading floor or specialists. Arguments for an ECN include the possibility of faster execution, greater transparency and better pricing. Archipelago owns and operates a major ECN.

17. Karmel, supra note 8, at 368 . 
Notes of caution have been sounded, however, as the merits of the nonprofit form are acknowledged. For instance, the nonprofit exchange is thought to be more responsive to regulation. ${ }^{18}$ It may also be that certain rules, including high listing standards and a difficult delisting process, helped firms that list on the NYSE signal their quality and commitment. ${ }^{19}$

We depart from the existing literature on demutualization by considering the possibility that the non-profit form actually created important efficiencies that will be lost upon demutualization. We view the nonprofit member firm as a more efficient form of organization than the newly emerging for-profit exchanges. We speculate later on why an entity would choose to demutualize when doing so would be inefficient. But we do note here that, in practice, the move to demutualize was less straightforward than the literature would suggest. That is, if demutualization were in fact more efficient, why has it taken so long to implement? The possibility of alternative trading systems based on computerized networks first emerged in the 1960s. The argument that the private club-like form of the Exchange was "archaic" was vetted in the 1930s. ${ }^{20}$ Yet, the first exchange to demutualize was Sweden's Stockholm Stock Exchange in $1993 .^{21}$ As early as 1999, NYSE President Richard Grasso testified to Congress that he was in favor of a shift to the for-profit form and that the Board of the Exchange had already begun the process. ${ }^{22}$ Yet the NYSE delayed the change, "apparently because of internal tensions." another seven years and a change in leadership to accomplish de-

18. James Cox, The Future Content of the U.S. Securities Laws: Premises for Reforming the Regulation of Securities Offerings: An Essay, 63 LAW \& CONTEMP. PROBS. 11 (2000); Macey and O'Hara, supra note 12, at 573.

19. Macey and O'Hara, supra note 12, at 570.

20. LOUIS LOSS \& JOEL SELIGMAN, SECURITIES REGULATION § 7-B-2 (3d ed. 2006) (citing William O. Douglas, Democracy AND FinanCE, 64-65 (1940) ("Operating as privatemembership associations, exchanges have always administered their affairs in much the same manner as private clubs. For a business so vested with the public interest, this traditional method has become archaic").

21. Karmel, supra note 8, at 368 .

22. Public Ownership of U.S. Stock Markets: Hearing Before the S. Banking, Housing, and Urban Affairs Comm., 106th Cong., Statement of Richard Grasso, Chairman and CEO of New York Stock Exchange, Inc., 1999 (stating that demutualization is "critically needed to assure the continued competitiveness and position of the NYSE as the world's preeminent equity market").

23. John C. Coffee, Jr., Racing towards the top?: The impact of cross-listings and stock market competition on international corporate governance, 102 COLUM. L. REV. 1757 (2002). 
mutualization. $^{24}$ One explanation, of course, is that the "entrenched" interests of "insular" Exchange members delayed the inevitable. $^{25}$ In fact, when the move to demutualize was finally made in the wake of the ouster of Grasso, a frequent view expressed in the media was that Grasso himself had blocked the reform in order to protect those entrenched interests. ${ }^{26}$ But in his Congressional testimony, Grasso raised many of the same arguments as those found in the scholarly literature. If the presumed leading defender of insular member interests at the Exchange was in favor of for-profit status yet was unable to carry out such a reform, an alternative explanation for the failure to complete the transition much earlier than 2006 is required. We contend that the nonprofit form benefited members, as well as the Issuing Firms and investors they served, and thus preserving with that structure was rational. ${ }^{27}$

\section{A CONSUMER-OWNED MODEL OF NONPROFIT ORGANIZATION}

While much of the scholarly literature on nonprofits mirrors the popular notion that they are inefficient, we apply a model that shows how nonprofits can be economically efficient, even achieving first-best efficiency. ${ }^{28}$ In this model, the highest demanding consumers of a nonrival good organize to produce the good. ${ }^{29}$ Because high demanders are able to organize, they also have more information about demand than a for-profit entrepreneur. This infor-

24. Significant shifts in NSYE governance structure have been rare. Stability has been the norm. The two most notable "constitutional moments" for the Exchange, prior to this year's transition, occurred in 1938 and 1971. In the wake of the Depression era, Whitney Scandal the Exchange opened up its Board of Governors to directors representing the investing public. After the "back office" crisis of the late 1960s the Exchange made a formal move to non-profit corporate status under New York law. See RICHARD J. TEWELES \& EDWARD S. BRADLEY, THE STOCK MARKET, 133 ( $7^{\text {th }}$ ed. 1998). For a discussion of the Exchange's ability to adopt new modern standards over time, see Mahoney, supra note 7.

25. Leon Lazaroff, NYSE trading on future stock sale, merger for future, CHI. TRIB., Feb. 26, 2006, at 9 ("That the NYSE is making this transition $21 / 2$ years after Grasso resigned is extraordinary when one considers the vigor with which observers said he resisted change in order to preserve specialist sovereignty").

26. Id. ("uproar over the former chairman and chief executive's hefty pay package was essential in forcing change on an insular institution").

27. We can, of course, only speculate as to the reasons for the delay. If Coffee, supra note 23 , is right that Grasso's push for a change was met with internal tension, that tension may have reflected debate over the relative value of retaining the hostage system versus the potential for short term gains by selling out one's membership.

28. Jennifer Kuan, The Phantom Profits of the Opera: Non-profit Ownership in the Arts as a Make-Buy Decision, 17 J. L., ECON. \& ORG. 2 (2001).

29. A nonrival good is one where one party's use of it does not diminish its value to others. 
mational advantage allows more efficient price discrimination and is the source of economic efficiency. The following is a simple numerical example to illustrate the basic idea, which we then apply to the NYSE.

Suppose a non-rival good of a certain quality costs $\$ 1000$ to produce (assume higher quality costs more, lower quality less). Demand consists of two "high" types and ten "low" types. High types have a high willingness to pay; in this case, both high types are willing to pay $\$ 500$ each for the good. Since the good is non-rival, their combined $\$ 1000$ is exactly enough to pay for the good. Low types have a low willingness to pay; in this case, each low type is willing to pay $\$ 10$. Together, the low types are only willing to pay $\$ 100$.

Assume that a profit-maximizing entrepreneur knows the demand curve, i.e. two high types willing to pay $\$ 500$ each and ten low types willing to pay $\$ 10$ each, but he cannot distinguish high types from low types. According to canonical price discrimination models, the entrepreneur must produce a lower quality product that sells at a price all can afford, or produce two goods, a high quality-high priced one and a low quality-low-priced one. In either case, the entrepreneur makes a profit, and the high types come away with some consumer surplus. That is, the entrepreneur and the high types share the surplus.

Assume also that high types know the demand curve; in particular, they know that they are the only two high types. Now suppose that the two high types have the ability to work together and produce the good themselves. Together, they put in $\$ 500$ each and produce a $\$ 1000$ quality good. Since the two high types know each other and their willingness to pay, they also know that the other ten consumers are low types. That is, they have perfect information about demand, something the entrepreneur did not have. They charge the low types $\$ 10$ to consume the good, which they then keep. They get the entire surplus, in this case, $\$ 100$ in total or $\$ 50$ each. Observe that this firm has the appearance of a nonprofit firm. Revenues for the good are $\$ 120$ ( $\$ 10$ each from 12 consumers). The cost of producing the good is $\$ 1000$. The high types make up the difference, or $\$ 880$. This amount appears to be a donation when, in fact, it comes from the high types' willingness to pay.

Since the high types have perfect information about demand, they reap the total surplus and can never do better by buying from a for-profit entrepreneur. What is needed for a nonprofit organi- 
zation, however, is 1) non-rivalry in the good and 2) the ability of high types to organize around their information. If the two high types did not know each other, or could not come together to pool their resources, then the nonprofit firm would not arise. In practice, these obstacles can be enormous. In the model derived by Kuan, wealthy members of "Society" who socialized regularly produced operas and used age-old rules of etiquette to extract contributions. $^{30}$ Note that these social pressures were essential to financing production and to economic efficiency, and a for-profit entrepreneur, who would have been an outsider, could not have used them. Thus, even if the entrepreneur had information about wealthy individuals, perhaps from the Social Registry, he would still need a mechanism for extracting payment. Society mavens have such a mechanism; entrepreneurs do not.

\section{THE NYSE AS A CONSUMER OWNED NONPROFIT}

How does a model of nonprofit organization - developed in the context of opera companies - apply to the NYSE? In the stylized model above, a nonprofit is formed to produce a nonrival good using mechanisms to extract contributions from high types. In the benign case of operas, opera performances are the nonrival good, and long-standing social rules serve as a mechanism among the wealthy to get rich patrons to pay their fair share. In the case of the NYSE, liquidity is a nonrival good produced by financial intermediaries who use a number of mechanisms to elicit truthful information from insiders at Issuing Firms.

\section{A. LIQUIDITY}

A stock exchange provides a marketplace for arms-length trading of securities; a marketplace that creates liquidity and all the benefits that liquidity brings. A world without such a marketplace would resemble today's private equity market where a small group of professionals raise funds with money from wealthy individuals and institutional investors. Typically, private equity firms include buyout funds that buy distressed firms and install new management, and venture capital firms that finance risky startups. Buyout funds purchase all of the outstanding shares of publicly traded firms, thus eliminating the separation of ownership 
and control enabling direct management of firm operations by the new owners. Venture capital firms use a variety of contractual constraints to control the managers of the startup firms they back. The wealthy individuals and institutional investors who invest in these private equity funds as limited partners of the professional managers lack an impersonal and liquid market for their investments. To exit a private equity investment before the prescribed date (usually ten years), an investor must find a buyer for her investment. A secondary market for these limited partnership interests now exists, but its available capital is still relatively small. In addition, general partners of private equity funds discourage limited partners from considering such an alternative exit. ${ }^{31}$ The absence of liquidity, of course, negatively impacts asset prices, even in publicly traded securities. ${ }^{32}$ Thus, the sale of limited partnership interests in private equity funds for pennies on the dollar is not unusual. ${ }^{33}$

In contrast to the severe constraints of such a private market, an ideal public market has prices that change smoothly, that can be observed almost continuously, and provides brokers, specialists or market makers who facilitate finding a buyer. The specialists and market makers are willing, even required, to serve as a buyer or seller of last resort. Also, with many buyers and sellers participating in the market, prices reflect the combined knowledge of these participants. ${ }^{34}$ Finally, recent corporate accounting scandals notwithstanding, NYSE-traded firms make regular and, far more frequently than not, accurate public disclosures. By contrast, venture capital funded start-ups are extremely risky, tight-lipped, and unpredictable.

31. Matthew Sheahan, Portfolio For Sale, VEN. CAP. J., June 1, 2005, available at http://www.ventureeconomics.com/vcj/protected/1110466090915.html (last visited Feb. 18, 2007).

32. Marc Reinganum, Market Microstructure and Asset Pricing: An Empirical Investigation of NYSE and Nasdaq Securities, 28 J. FIN. ECON. 127 (1990); David Easley, Soeren Hvidkjaer, and Maureen O'Hara, Is Information Risk a Determinant of Asset Prices?, $57 \mathrm{~J}$. FIN. 2185 (2002); M.J. Brennan \& A. Subrahmanyam, Market Microstructure and Asset Pricing: On the Compensation for Illiquidity in Stock Returns, 41 J. FIN. ECON. 441 (1996); and Alexander W. Butler, Gustavo Grullon \& James P. Weston, Stock Market Liquidity and the Cost of Raising Capital (2002), available at SSRN: http://ssm.com/abstract $=354720$ (last visited Feb. 18, 2007).

33. Interview with one of the authors, partner, secondary venture capital fund, 2005 (transcript on file with author).

34. The NYSE requires even heavily traded listed companies to have a minimum of 500 shareholders while companies conducting an IPO must have 2000 shareholders. See NYSE, Inc., Listed Company Manual $\$ 102.00$, available at http://www.nyse.com/ Frameset.html?nyseref $=$ http\%3A/www.nyse.com/regulation/listed/1147474807344.html\&displayP age $=/ \mathrm{cm} / 1078416930672 . \mathrm{html}$ ? enable $=$ subsection \& snumber $=1 \& \&$ \&snumber $=102.00$ (last visited Mar. 12, 2007). 
The ease of trading and abundant information that a NYSE listing brings to individual investors has helped generate wide participation in the stock market by individual, so-called "retail," investors. This widespread participation increases liquidity and, therefore, benefits the firms whose shares trade on the NYSE. Thus the NYSE, as an intermediary institution, serves investors and listing firms by creating price enhancing liquidity. We will argue in the next sections that the NYSE does this by ensuring information is reliable and truthful, thus solving a "lemons" problem.

\section{B. OWNERS}

According to a consumer-owned model, the owners of a nonprofit are also the consumers with the most to gain. While liquidity benefits all investors and publicly traded firms, the biggest beneficiaries are, in principal, easily identified as NYSE "seat holders" or members. Unfortunately, seat holders are identifiable to us in principal only because, in practice, membership rolls are private information. Nevertheless, press estimates and De Long's historical account each suggest that investment banks dominate membership decisions. ${ }^{35}$

There are members with other functional expertise, however, such as broker-dealers, who service retail customers. By providing millions of small investors with access to the NYSE, brokerdealers provide a valuable component of liquidity. Specialists are firms that manage the trading activity for issuing firms. Each issuing firm selects a single specialist firm, giving that specialist a monopoly over transactions in that issuing firm's stock. A lucrative business, specialists also provide a valuable service to the Exchange, acting as buyer and seller of last resort. As such, the specialist uses her own account to ensure that prices move in small increments. While maintaining price quality can be risky - stock market crashes have put many a specialist out of business - it also contributes to investor confidence. On ECN's, in contrast, where customers' buy and sell orders are matched with each other, thin after hours trading has produced large, unsettling price discontinuities.

Each of these three types of members of the NYSE serves an important function for the nonprofit. Certain mechanisms hold

35. De Long, supra note 7. 
these fiercely competitive firms together within the Exchange, constraining their behavior for the production of liquidity, the nonrival good that they can each benefit from. Among these mechanisms are internal rules and multi-lateral contracts. However, for the purposes of this paper, we focus on the information problem associated with liquidity and the use of hostages to support a solution to that problem.

\section{THE "LEMONS" PROBLEM AND THE ROLE OF INFORMATION QUALITY}

There are a number of inputs into the production of liquidity. Typically, the existing literature explores the positive effect that regulation has had on expanding the volume of trading on equity markets and the positive role that an independent judiciary has on enforcing privately negotiated contracts. Less attention has been paid, however, to the effect that quality of information has on stock markets. In the wake of the most recent corporate scandals, where, for example, fraudulent disclosures were used by Enron to cheat investors, we believe that providing information remains a problem for exchanges even with regulation and a supportive contract law regime.

As suggested above, Akerlof argued that the used-car market suffers from a similar information problem. ${ }^{36}$ In this market, information about the quality of a faulty used car, a so-called "lemon," is indistinguishable from the information about a nonfaulty used car because of the information asymmetry between buyers and sellers. Thus, buyers must apply a lemon discount to all cars that depresses the price for good and bad used cars alike and thus, in turn, discourages owners of non-faulty used cars from entering the market. The result is that, like Gresham's Law (bad money drives out good), lemons drive out non-lemons, in a race to the bottom.

In the context of stock exchanges, Macey and O'Hara recognize the potential for opportunism and the role of the NYSE's selfregulatory arm in countering it. ${ }^{37}$ They argue that it is important to recognize the difference between the ex ante willingness of an issuer "to opt into a set of efficient legal rules to prevent or impede later diversions of wealth from investors" such as those required

36. Akerlof, supra note 4.

37. Macey and O'Hara, supra note 12 , at 585-588. 
by a demanding self regulated exchange and the ability of an issuer, ex post, to take advantage of a world which offers multiple listing venues some of which may be indifferent to such opportunistic behavior. ${ }^{38}$ Thus, "management has an incentive to renege on the agreements it has made with investors whenever possible. In today's environment of multi-venue trading, the problem of such ex post opportunistic behavior looms quite large.

Issuing firms have much to gain by misrepresenting information, whether that information comes from accounting records, clinical tests, or business prospects. Recent history has shown that there are myriad ways to deceive the investing public and myriad incentives to do so. Thus, when it comes to the production of quality information, the problem is one of eliciting truthful disclosure from Issuing Firms.

\section{MECHANISMS}

How do owners of the NYSE elicit the truth? We focus on investment banks because they have the most information about Issuing Firms, and, as intermediaries between firms and investors, probably also have the most to lose from deceit. We identify two methods that bankers use to overcome information asymmetry: gate-keeping and hostages.

\section{Gate-keeping}

Bankers gather information about a prospective issuer through two distinct processes. First, bankers select among potential candidates those firms they believe meet a certain quality standard and are ready to consider "going public." Second, the lead underwriters chosen to lead a stock offering conduct an intensive "due diligence" or investigation process, which can often take months, to verify the quality and accuracy of the information that the issuing firm will disclose to potential investors. During the due diligence process, bankers work with issuers to prepare a registration statement, including a prospectus to be provided to potential investors, containing that information that is filed with the SEC and the NYSE. The registration statement must contain all material information necessary for a reasonable investor to decide whether or not to purchase the offered security, including financial state- 
ments prepared by management that are audited by an outside accounting firm. The registration process gives bankers an opportunity to evaluate the management and business prospects of an issuing firm, and also to build long-term personal relationships with managers. Obtaining information through first-hand contact with firms is a time-tested method. For instance, De Long describes the early $20^{\text {th }}$ century role of J.P. Morgan's "men" in improving firm management through Morgan's investment banking relationship with such firms. ${ }^{40}$

\section{Hostage exchange}

Solving the lemons problem requires more than gate-keeping, however. Keeping issuers honest is an on-going problem. To confront this problem we believe that bankers engage in the exchange of hostages. Bankers use the IPO process to extract hostages from issuer insiders. These hostages help align the incentive of issuers to disclose with the need of investors for quality information.

\section{a. Hostages}

The idea of using hostage exchange to align incentives is suggested by Oliver Williamson. ${ }^{41}$ According to Williamson, in a transaction, buyer and seller offer each other hostages to guarantee against cheating. If the buyer cheats, the seller may keep the hostage posted by the buyer; if the seller cheats, the buyer keeps the hostage posted by the seller. Examples of hostages have, in practice, been hard to find, especially in a buyer-seller context. However, Kuan offers evidence of hostage exchange among venture capitalists in the early period of venture capital activity on the east coast. ${ }^{42}$ In that setting, a lead VC's role as the manager of an investment in a start-up places him in a position to cheat a less-informed fellow investor. A VC who has a close or proprietary relationship with an entrepreneur can use the resulting asymmetry to cheat through shirking or misrepresenting information. In this case, Kuan found, the incentive to cheat fellow members of a VC syndicate was mitigated by a reciprocal investment that placed the lead investor in a follower position in a subsequent start-up with fellow VC's. That is, in the first start-up, one VC is

40. De Long, supra note 7.

41. Oliver Williamson, MEchanisms of Governance (1996).

42. Kuan, supra note 5. 
the leader and the other VC is the follower. In the next start-up, the VC's swap roles. This swapping of leadership roles provides each VC the opportunity to punish cheating. The result of the hostage exchange is deterrence.

In the VC setting, hostages are effectively generated and thus can be exchanged because the lead $\mathrm{VC}$ is an active manager of its start-up. A lead VC's efforts influence business outcomes; therefore, if a lead VC shirks, the start-up suffers. Thus, VC's know that the hostage exchange process is significant. At the NYSE, CEO's and other top insiders influence the outcome of firms; bankers only obtain quality information from firms if they can threaten senior insiders. So, it is the CEO from whom a hostage must be extracted, if truthful information about a firm is to be obtained.

\section{b. The IPO process}

One way we think bankers extract hostages is to use IPO allocations. When a corporation decides to conduct a public offering of its securities, it will typically contract with an investment bank to serve as the lead manager of the offering process. ${ }^{43}$ The lead manager will usually organize an underwriting syndicate in order to spread the risk of completing the offering among several investment banks. The lead manager will reap the largest fees from the offering, and has the right to determine the relative size and structure of the "allocation" of securities. A certain percentage of securities will be allocated to institutional investors, usually around $70 \%$ of the overall offering, with the remaining $30 \%$ allocated to retail investors. There are several competing pressures faced by the lead manager during the allocation process. On the one hand, if the offering is on a "firm commitment" basis, the underwriting syndicate and the issuer will enter into an underwriting agreement, obligating the banks to purchase the entire offering amount. Thus, the banks put their own capital at risk and are under pressure to "build a book" of investors who indicate an interest in the purchase of the securities once the SEC registration process is complete. There is also an interest in placing the shares with investors who are willing to hold them for a relatively long period of time. Issuers typically view such a shareholder base as

43. It is technically possible, but relatively unusual, for an issuer to offer its securities without the assistance of a financial intermediary such as an investment bank. 
easier to manage, and the wider market enjoys a more efficient price because long term, particularly institutional, holders are often in a better position to monitor managers. For this reason, lead managers impose a penalty on broker-dealers who place shares with customers that "flip" their allocated shares too quickly. ${ }^{44}$

To see how volatile prices can be if large investors also flip, consider the Internet bubble experience of the late 1990s, when even normally restrained IPO shareholders began to flip. Ljungqvist and Wilhelm found that:

In 1996, first-day returns on initial public offerings averaged about 17 percent (median: 10 percent). In 1999, first-day returns averaged 73 percent (median: 40 percent) before tapering off to 58 percent (median: 30 percent) in 2000. Internet IPO's averaged a stunning 89 percent (median: 57 percent) during 1999 and 2000 . These average returns dwarf those from earlier periods and are the most widely recognized feature of what is now commonly referred to as the "dot-com bubble. ${ }^{\text {45 }}$

Similarly, Ritter and Welch find first day "underpricing" averaged only $7 \%$ in the 1980's, yet shot up to $65 \%$ in 1999 and $2000 .^{46}$ Prior to this anomalous period, however, bankers could ordinarily count on allocating shares in new offerings to clients who would hold those shares for an extended period of time. In that case, those clients might be risking a sacrifice; over a 5-year period, IPO shares performed below the market. ${ }^{47}$

\section{c. IPO allocations as hostages}

Allocating IPO shares to clients allows bankers to achieve two goals. Price stabilization is the first, but creating mutual dependencies is the other. Like interlocking directorships, IPO allocations create personal and business connections among issuer insiders. In a rare public disclosure of this practice, Citigroup, the

44. Charles Johnson, JR. \& Joseph Mclaughlin, Corporate finance and the SECURITIES LAWS, 71-72 (1997).

45. Alexander Ljungqvist \& William J. Wilhelm, Jr., IPO Pricing in the Dot-com Bubble, 58 J. FIN. 723 (2003).

46. Jay R. Ritter \& Ivo Welch, A Review of IPO Activity, Pricing, and Allocations, 57 J. FIN. 1795 (2002).

47. Loughran, Tim and Jay R. Ritter, The New Issues Puzzle, 50 J. Fin. 23 (1995); Jay Ritter, The Long-run Performance of Initial Public Offerings, 42 J. Fin. 365 (1991). 
parent company of investment bank SalomonSmithBarney (SSB), provided a description of the IPO allocation process to the U.S. House of Representatives, in response to a subpoena issued during a Congressional investigation in 2002. One bank document lists the allocations made to more than two-dozen people, many of them CEOs at publicly listed firms. ${ }^{48}$ Under ordinary (non-bubble) circumstances, these CEOs would hold onto their IPO shares, thus becoming partial owners of the newly listed firm. The CEOs are then vulnerable to drops in share price caused by insider shirking or fraud. This vulnerability places the new firm under increased scrutiny by fellow CEOs. Also, to the extent that fellow CEOs can punish each other for transgressions, perhaps through foreclosure of any future dealings, this creates an incentive to disclose information.

This interpretation of IPO allocations is, of course, exactly the opposite of what IPO allocations came to represent, namely a perk. As indicated above, in the late 1990s a significant increase in the price of IPO shares during the first few days of trading was almost guaranteed. The most notorious recipients of these unusual allocations were the so-called "Friends of Frank," a circle of prominent CEO's and other senior insiders in Silicon Valley who regularly received IPO shares from prominent investment banker Frank Quattrone of CSFB. ${ }^{49}$ Because tech boom era stocks consistently exhibited significant price hikes in the immediate post-IPO period, these allocations were viewed more as more akin to a bribe to win new clients than as a hostage aimed at ensuring quality disclosure from issuers over a longer period of time.

\section{Discussion and Conclusions}

On March 8, 2006, the opening bell at the NYSE was greeted by a mixture of applause and boos. Announcing the arrival of a publicly traded for-profit NYSE, the negative reaction came mostly from the exchange's own floor traders. For them, the implications of demutualization were clear: an end to their way of life, as floor trading is gradually replaced by on-line order matching. Executives at the NYSE are also being replaced, one after another, by Archipelago executives. The replacement of the NYSE by a super-

48. Jane C. Sherburne, Citigroup, Letter to Hon. Michael G. Oxley and Hon. John J. LaFalce, Committee on Financial Services, U.S. House of Representatives, Aug. 30, 2002.

49. Pradnya Joshi, Rise and Fall Of Banking Star; Quattrone Rode Tech Boom, Bust, NEWSDAY, April 24, 2003, at A44. 
sized Archipelago, and the plans of John Thain, the NYSE Group's CEO, to acquire overseas exchanges, is part and parcel of what we predict at the NYSE, namely, a gradual degradation of quality.

As the world's premier stock exchange, the NYSE has had imitators around the world. Yet it has maintained a position of leadership, with the highest valuations, the largest market capitalization, and the biggest trading volumes, even without the largest number of issuers. ${ }^{50}$ Incumbency alone, however, cannot explain this superior performance, as entrants have tried and failed over time to displace the NYSE. One explanation for the NYSE's performance is its higher level of integrity, i.e., its successful resolution of the lemons problem. One way it may have solved the lemons problem is through the use of a hostage exchange system embedded within the nonprofit form. For various reasons, including the difficulty of observing the system itself, this solution is difficult to imitate. It may also be the case that over time those who recognize the advantage of a hostage based system have moved into other settings, particularly the private equity world where as suggested, at least as far as the VC environment is concerned, there is an established hostage exchange process. That leaves the public trading markets exposed to the potential downside of a slide into a hostage-free world of commoditized trading.

Under the nonprofit model, exchange-owning bankers had an incentive to be selective about which firms traded on the NYSE. Solving the lemons problem led to greater investor confidence and hence liquidity, which in turn meant more and higher underwriting fees. Increased activity by small individual investors would profit broker-dealers directly rather than investment banks which deal only with issuing firms and large investors. So limiting the firms that trade on the NYSE to only those who meet certain listing standards and whose most important managers post hostages benefits bankers through higher fees from listed firms. Banks thus profit only indirectly from greater liquidity.

A for-profit exchange, like Archipelago, profits directly from liquidity, charging investors for each buy or sell transaction. A forprofit exchange benefits only indirectly from investor confidence that results from solving the lemons problem, so maintaining the quality of firms and the quality of information is of interest only

50. Hughes and Authers, supra note 3, at 13 ("The market value of companies traded on New York's floor is $\$ 21,000$ billion - more than the Tokyo, London, Nasdaq, Euronext and Deutsche Boers exchanges combined."). 
indirectly. Given these incentives, we would predict a reduced incentive for the new for-profit NYSE to maintain informational integrity. In turn, this is likely to lead to an increase in the growth rate of firms allowed to list and hence an overall decline in investor confidence.

One question arises from our dire predictions, namely, if the mutual form of organization is so great, why would the exchange choose to demutualize? One possibility is that a form of market segregation is now occurring in capital markets. Technological change is both driven by, and combined with, the rise of institutional investors who value speed of execution over best price. Thus, with the growth of web-based computing power, a market for trading as a commodity has opened up. That has created a new form of competition for the traditional exchanges from the alternative trading systems, first Nasdaq and then Archipelago, Instinet and others. Rather than beat them, the NYSE has decided it is best to join them. Meanwhile, private equity and other forms of off-exchange trading of financial instruments seem to offer much higher rewards to individuals who might have gone into traditional investment banking several years ago.

In the off-exchange world, it is once again possible to recreate stable hostage systems. This is particularly the case in markets that are controlled by certain key players with a first mover advantage: those who build the club, so to speak, get to set the rules. One of us has already demonstrated the importance of this approach to understanding the origins of the highly successful venture capital environment. ${ }^{51}$ It now remains to apply the approach pioneered by Williamson to the emerging frontiers of finance.

51. Kuan, supra note 5 . 